$1-1-1927$

\title{
A Balanced and an Unbalanced Ration Fed Prior to the Hatching Season as Affecting the Hatchability of Eggs and the Vigor of the Progeny
}

Horace Atwood

Follow this and additional works at: https://researchrepository.wvu.edu/ wv_agricultural_and_forestry_experiment_station_bulletins

\section{Digital Commons Citation}

Atwood, Horace, "A Balanced and an Unbalanced Ration Fed Prior to the Hatching Season as Affecting the Hatchability of Eggs and the Vigor of the Progeny" (1927). West Virginia Agricultural and Forestry Experiment Station Bulletins. 207.

https://researchrepository.wvu.edu/wv_agricultural_and_forestry_experiment_station_bulletins/207 @ WVU. It has been accepted for inclusion in West Virginia Agricultural and Forestry Experiment Station Bulletins by an authorized administrator of The Research Repository @ WVU. For more information, please contact ian.harmon@mail.wvu.edu. 
West Virginia University Libraries 
ENASDALE LIBRARY WEST VRGINIA UMVERSTY 


\section{Restricted}

Circulation Only

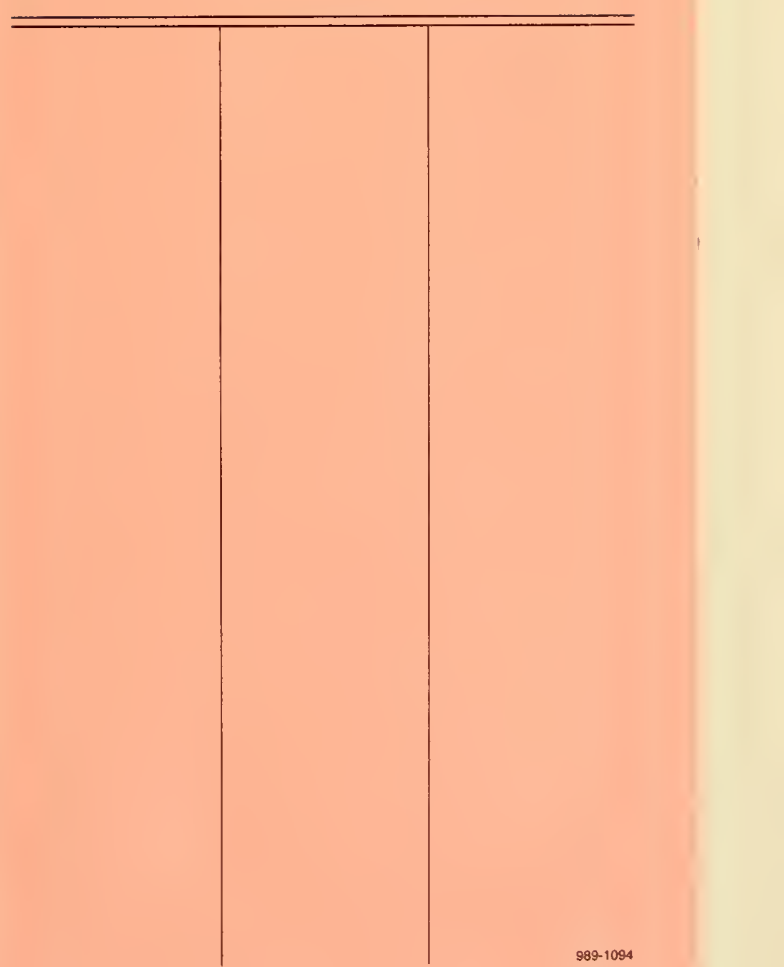





\section{Aqrícultural Experiment Station}

College of Agriculture, ratest Birginia Annibersity

\section{HENRY G. KNIGHT, Director \\ Morgantown}

A Balanced and An Unbalanced Ration Fed Prior to the Hatching Season As Affecting the Hatchability of Eggs and the Vigor of the Progeny

(Technical)

By

HORACE ATWOOD

Publications of this Station will be mailed free to any citizen of West Virginia upon written application. Address Director of the West Virginia Agricultural Experiment Station, Morgantown, West Virginia. 


\section{AGRICULTURAL EXPERIMENT STATION STAFF}

FRANK BUTLER TROTTER, A. M., LL. D............. President of the University HENRY G. KNIGHT, Ph. D................ Dean of the College of Agriculture and Director of the Experiment Station WALTER C. SCHNOPP, B. S., Agr................... Agricultural Editor

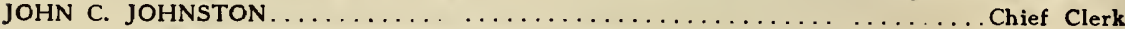

\section{AGRONOMY}

R. J. Garber, Ph. D.

E. P. Deatrick, Ph. D. Associate Soil Technologist

T. E. Odland, Ph. D. Associate Agronomist

T. C. Mcllvaine, Ph. D. $\dagger$ Assistant Agronomist

D. R. Dodd, M. S. Assistant Agronomist

M. M. Hoover, M. S. Junior Agronomist

H. K. Rowley, M. S. Agr.**

Seed Analyst

\section{ANIMAL HUSBANDRY}

E. A. Livesay, M. S

Animal Husbandman

Chas. V. Wilson, M. S.

Assistant Animal Husbandman

J. H. Longwell, M. S. Assistant Animal Husbandman

J. H. Rietz, D. V. M.

Associate Veterinarian.

R. H. Tuckwiller, B. S. Agr.*

Assistant Animal Husbandman

\section{CHEMISTRY}

R. B. Dustman, Ph. D.

Associate Chemist

Chas. E. Weakley, Jr., B. A.

$$
\text { Assistant Chemisı }
$$

L. P. Hansen, Ph. D.

Assistant Chemist

T. B. Leith, B. A.** Assistant Chemist

Paul Daughenbaugh

$$
\text { Assistant in Chemistry }
$$

\section{DAIRY HUSBANDRY}

E. L. Anthony, M. S. Agr.

Dairy Husbandman

H. O. Henderson, M. S. Agr.

Associate Dairy Husbandman

G. Malcolm Trout, M. S.

Junior Dairy Husbandman

\section{ENTOMOLOGY}

L. M. Peairs, Ph. D.

Entomologist

W. E. Rumsey, B. S.** State Entomologist

L. E. Dills, B. S.**

Assistant in Entomology

\section{FARM ECONOMICS}

A. J. Dadisman, Ph. D.

Paul A. Eke, Ph. D.

Assistant Farm Economist

F. D. Cornell, Jr., M. S.

Junior Farm Mechanician

W. W. Armentrout, M. S.

Junior Farm Economist

HOME ECONOMICS

Rachel H. Colwell, A. M.

Home Economist

Hazel C. Cameron, M. S.

Research Specialist in Foods

Nell Nesbitt, A. M.

Research Specialist in Home Mana't

\section{HORTICULTURE}

H. L. Crane, M. S. Agr.

Associate Horticulturist

H. E. Knowlton, $\mathrm{Ph}$. D.

Associate Horticulturist

K. C. Westover, M. S. Agr.

Assistant Horticulturist

Ernest Angelo, M. S. Agr.

Junior Horticulturist

L. F. Sutton, B. S. Agr. $\ddagger$

Assistant Horticuiturist

H. P. Sevy, M. S. Agr.

Assistant in Horticulture

M. B. Hoffman, M. S.

Assistant in Horticulture

\section{PLANT PATHOLOGY}

N. J. Giddings, Ph. D. Plant Pathologist

Anthony Berg, M. S

Assistant Plant Pathologist

L. H. Leonian, $\mathrm{Ph}$. D.

Assistant Plant Pathologist

E. C. Sherwood, M. S.

Assistant Plant Pathologist

\section{POULTRY HUSBANDRY}

Horace Atwood, M. S. Agr.

Poultry Husbandman

E. T. Wightman, M. S. Agr.

Junior Poultry Husbandman

RURAL SOCIOLOGY

T. L. Harris, Ph. D.

Rural Sociologist

\section{ZOOLOGY}

F. E. Chidester, Ph. D.

Zoologist

*In cooperation with the U. S. Department of Agriculture, Washington, D. C.

†ln charge of the Lakin Sub-Station, Lakin, W. Va.

**In cooperation with the State Department of Agriculture, Charleston, W. Va.

$\ddagger$ In charge of the Reymann Memorial Farms, Wardensville, W. Va. 


\section{A BALANCED AND AN UNBALANCED RATION FED PRIOR TO THE HATCHING SEASON AS AFFECTING THE HATCH- ABILITY OF EGGS AND THE VIGOR OF THE PROGENY}

The period during which hens can produce eggs profitably is usually limited to the first two years of their lives. This makes it nec. essary, in practice, to replace about one-half of the laying flock with pullets each fall, and as this requires raising at least twice as many chickens as there are birds in the laying flock any information which sheds light on the factors which affect the hatchability of eggs or the vigor of chickens is of practical importance to the poultryman.

Does heavy laying during the winter and early spring months measurably decrease the hatchability of the eggs, or the vigor of the progeny produced later in the season? If this should be the case it would be necessary, for best results, to feed and manage the breeding flock so that few eggs would be produced during the period immediately prior to the hatching season.

The experiment herein reported was planned to give the informa tion desired.

\section{General Plan of the Experiment}

The experiment was begun November 1, 1923, and was concluded September 19, 1925. The fowls used were Single Comb White Leghorns of the strain developed at the West Virginia Agricultural Experiment Station. The birds were hatched May 9, 1923, and they were raised under practically free range conditions.

Six pens of fowls were employed, each consisting of 16 female birds. They were housed in separate colony houses, numbered 4 to 9 . and trapped. During the winter of 1923-24 the fowls in houses 5, 8, and 9, hereafter designated as Lot 1, were fed for egg production, while the other fowls were fed principally upon whole grain so that few eggs were laid. During the succeeding winter, however, the rations were reversed, the fowls in Lot 2 being fed for eggs and those in Lot 1 receiving the whole grain ration.

In the spring of 1924 and also in 1925 eggs laid by these fowls were incubated and a record was kept of the fertility and hatchability of the eggs and the mortality and rate of growth of the offspring.

\section{RATIONS USED}

The mixture of whole grain consisted of two parts by weight of yellow corn, two parts of wheat, and one part of oats. The mash was composed of two parts of yellow corn meal, and one part each of wheat bran, wheat middlings, and meat scrap. The mash was self-fed in hoppers and the whole grain in straw litter. The fowls fed for egg 
production also received a moderate allowance of semi-solid buttermilk. The fowls fed for low egg production were fed liberally upon the whole grain mixture until a short time before eggs were saved for hatching. Then these fowls, also, received mash and semi-solid buttermilk.

WEIGHING THE FOWLS

Each bird was weighed at the beginning of each calendar month, beginning November 1, 1923. This was done at night soon after the birds had assembled on the perches.

Table 1 shows the number of pounds of feed consumed by each lot of 48 fowls per month, the total number of eggs laid per month, and the average weight of the birds.

TABLE 1.-Feed Consumed, Eggs Laid, and Average Weight of Birds by Months for Lots 1 and 2 During the First Year.

\begin{tabular}{|c|c|c|c|c|c|}
\hline \multicolumn{6}{|c|}{ Lot 1. Pens 5, 8, and 9, Fed for High Egg Production } \\
\hline Months & $\begin{array}{c}\text { Pounds } \\
\text { Whole Grain }\end{array}$ & $\begin{array}{l}\text { Pounds } \\
\text { Mash }\end{array}$ & $\begin{array}{c}\text { Pounds } \\
\text { Semi-Solid } \\
\text { Buttermilk }\end{array}$ & $\begin{array}{l}\text { Number of } \\
\text { Eggs Laid }\end{array}$ & $\begin{array}{l}\text { Average weight } \\
\text { of Birds in } \\
\text { Pounds }\end{array}$ \\
\hline $\begin{array}{c}1923 \\
\text { November }\end{array}$ & 181 & 83 & 45 & 408 & 3.22 \\
\hline December & 175 & 122 & 46 & 395 & 3.49 \\
\hline $\begin{array}{c}1924 \\
\text { January }\end{array}$ & $1 \leqslant 9$ & 114 & 46 & 173 & 3.57 \\
\hline February & $15 c$ & 114 & 43 & 529 & 3.67 \\
\hline March & 154 & 165 & 48 & 1012 & 3.68 \\
\hline April & 167 & 183 & 46 & 1109 & 3.64 \\
\hline May & 173 & 181 & 46 & 1084 & 363 \\
\hline June & 172 & 150 & 38 & 964 & 3.54 \\
\hline July & 164 & 171 & 35 & 877 & 3.61 \\
\hline August & 132 & 158 & 35 & 632 & 3.37 \\
\hline September & 119 & $14 i$ & 33 & 301 & 3.37 \\
\hline October & 131 & 117 & 35 & 128 & 3.41 \\
\hline Total & 1894 & 1699 & 496 & 7612 & \\
\hline
\end{tabular}


TABLE 1.-Continued.

Lot 2, Pens 4, 6, and 7, Fed for Low Egg Production

\begin{tabular}{|c|c|c|c|c|c|}
\hline Months & $\begin{array}{c}\text { Pounds } \\
\text { Whole Grain }\end{array}$ & $\begin{array}{l}\text { Pounds } \\
\text { Mash }\end{array}$ & $\begin{array}{l}\text { Pounds } \\
\text { Semi-Solid } \\
\text { Buttermilk }\end{array}$ & $\begin{array}{l}\text { Number of } \\
\text { Eggs Laid }\end{array}$ & $\begin{array}{l}\text { Average weight } \\
\text { of Birds in } \\
\text { Pounds }\end{array}$ \\
\hline $\begin{array}{c}1923 \\
\text { November }\end{array}$ & 188 & 60 & 21 & 323 & 3.09 \\
\hline December & 195 & 60 & & 200 & 3.30 \\
\hline $\begin{array}{c}1924 \\
\text { January }\end{array}$ & 245 & & & 39 & 3.34 \\
\hline February & 237 & & & 175 & 3.23 \\
\hline March & 244 & & & 429 & 3.32 \\
\hline April & 221 & & & 259 & 2.89 \\
\hline May & 171 & 146 & 33 & 842 & 2.57 \\
\hline June & 171 & 154 & 38 & 1036 & 3.29 \\
\hline July & 164 & 173 & 35 & 940 & 3.33 \\
\hline August & 132 & 159 & 35 & 843 & 3. 27 \\
\hline September & 126 & 135 & 33 & 566 & 3.20 \\
\hline October & 132 & 117 & 35 & 205 & 3.32 \\
\hline Total & 2226 & 1004 & 230 & 5857 & \\
\hline
\end{tabular}

Lot 1 , which received the better balanced ration during winter, consumed 4089 pounds of grain, mash, and semi-solid buttermilk and laid 7,612 eggs, while Lot 2 consumed only 3,460 pounds of these feeds and laid 5,857 eggs. This illustrates the fact that the :better the ration the more the fowls will eat and the better they will lay. It may be observed, also, that the maximum rate of egg production in the case of Lot 1 was during April and May, while with Lot 2 the maximum was reached about a month later.

The ration of whole grain only during January, February, March, and April had a marked effect upon the weight of the birds. On May 1 , at the expiration of the period of exclusive whole grain feeding, the 
birds in Lot 2 averaged 2.57 pounds in weight or nearly one-half pound less than they weighed six months earlier and this decrease had taken place in spite of the fact that they were fed all of the whole grain mixture that they would consume. On the other hand the birds in the other lot on the better balanced ration had an average weight of 3.63 pounds, or a difference in the weight of the fowls in the two lots of more than one pound per bird. With the addition of mash and semi-solid buttermilk to the ration for Lot 2 these birds rapidly increased in weight and also in the rate of egg production.

The influence of the two rations used during the four months on the mean weight of the eggs laid during that period has been discussed in West Virginia Experiment Station Bulletin No. 201 entitled, Some Factors Affecting the Weight of Eggs.

HATCHING THE EGGS

A white Leghorn cockerel was placed with each pen of 16 birds, and beginning a few days before and during the time when eggs were saved for hatching these males were systematically and regularly changed daily from one pen to another so as to avoid as far as possible the effect of any possible difference in the breeding abilities of the males.

Two hatches were made in Cyphers 400 egg incubators. For the first hatch eggs were saved from May 15 to May 20 and the incubator was started May 21. For the second hatch the eggs were saved from May 21 to May 26 and the eggs set on the following day. Table 2 gives the details of the two hatches.

TABLE 2.-Fertility and Hatchability of Eggs Laid by the Two Lots of Fowls.

\begin{tabular}{|c|c|c|}
\hline Data Recorded for First Hatch & Lot 1 & Lot 2 \\
\hline Number of eggs incubated .... & 194 & 188 \\
\hline Per cent of eggs hatched & 83 & 74 \\
\hline Per cent of eggs fertile. & 9 I & 92 \\
\hline Per cent of fertile eggs hatched & 91 & 80 \\
\hline Data Recorded for Second Hatch & Lot 1 & Lot 2 \\
\hline Number of eggs incubated & 192 & 207 \\
\hline Per cent of eggs hatched & 88 & 85 \\
\hline Percent of eggs fertile $\ldots \ldots \ldots$ & 94 & 94 \\
\hline Per cent of fertile eggs hatched & 93 & 90 \\
\hline
\end{tabular}


The fertility was almost the same in the egys from both lots of fowls. In the first hatch the hatchability was greater in the eggs from Lot 1 , but in the second hatch the difference was slight.

\section{RAISING THE CHICKENS}

The chicks were toe marked and brooded in Mammoth brooders. Both lots ran together and were given free range. The birds were weighed individually on September 13 at which time those of the first hatch were 94 days old and those of the second hatch 88 days old.

Deaths from weakness or disease were reasonably low as only 5.7 per cent of the progeny of the fowls in Lot 1 died, and 2.5 per cent of Lot 2.

Table 3 shows the number of chicks weighed, the sex, and the mean weight of the birds hatched from eggs laid by the two lots of fowls.

TABLE 3.-Weight of Chickens on September 13, 1924, for the Two Hatches.

Data Recorded for First Hatch

Number of males

Number of females

Mean weight of males

Standard deviation in weight of males

Mean weight of females

Standard deviation in weight of females

Data Recorded for Second Hatch

Number of males

Number of females

Mean weight of males

Standard deviation in weight of males

Mean weight of females

Standard deviation in weight of females
Lot 2

77

54

$2.60 \pm .02$

$2.62 \pm .02$

$212 \pm .012$

$.236 \pm .013$

$2.04 \pm .02$

$2.06 \pm .01$

$.145 \pm .008$

$.191 \pm .012$

Lot 2

90

78

$2.31 \pm .02$

$2.37 \pm .02$

$.244 \pm .014$

$.265 \pm .013$

$1.86 \pm .02$

$1.85 \pm .02$

$.193 \pm .010$

$.225 \pm .012$ 
The table shows that there was no significant difference in the weight of the chickens resulting from the two different ways of feeding the breeding stock. There also was no significant difference in variability in weight. The males averaged about one-half pound heavier than the females.

\section{Second Year of Test}

During the second year the experiment was conducted on the same lines as during the first year, with the exception that the rations were alternated as has been already explained.

Table 4 shows the amount of feed consumed, number of eggs laid, and the average weight of the birds during the second year of the test.

TABLE 4.-Feed Consumed, Eggs Laid, and Average Weight of Birds by Months for Lots 1 and 2 During the Second Year

Lot 1, Pens 5, 8, and 9, Fed for Low Egg Production

\begin{tabular}{|c|c|c|c|c|c|}
\hline Months & \begin{tabular}{|c} 
Pounds \\
Whole Grain
\end{tabular} & $\begin{array}{l}\text { Pounds } \\
\text { Mash }\end{array}$ & $\begin{array}{l}\text { Pounds Semi- } \\
\text { solid Butter- } \\
\text { milk }\end{array}$ & $\begin{array}{l}\text { Number of } \\
\text { Eggs Laid }\end{array}$ & \begin{tabular}{|c} 
Average Weight \\
of Birds in \\
Pounds
\end{tabular} \\
\hline $\begin{array}{c}1924 \\
\text { November }\end{array}$ & 142 & 118 & 34 & 77 & 3.40 \\
\hline December & 139 & 111 & & 11 & 3.43 \\
\hline $\begin{array}{c}1925 \\
\text { January }\end{array}$ & 240 & & & 15 & 3.74 \\
\hline February & 242 & & & 111 & -4.09 \\
\hline March & 239 & & & 272 & 4.11 \\
\hline April & 240 & & & 499 & 3.87 \\
\hline May & 142 & 135 & 30 & 831 & 3.24 \\
\hline June & 73 & 230 & 33 & 941 & 4.12 \\
\hline July & 69 & 228 & 34 & 8.21 & 3.66 \\
\hline August & 79 & 226 & 34 & 639 & 3.73 \\
\hline September Ist & & & & & 3.62 \\
\hline $\begin{array}{c}\text { Total } \\
(10 \text { months })\end{array}$ & 1605 & 1048 & 165 & 4217 & \\
\hline
\end{tabular}


TABLE 4.-Continued.

Lot 2, Pens 4, 6, and 7, Fed for High Egg Production

\begin{tabular}{|c|c|c|c|c|c|}
\hline Months & $\begin{array}{l}\text { Pounds } \\
\text { Whole Grain }\end{array}$ & $\begin{array}{l}\text { Pounds } \\
\text { Mash }\end{array}$ & $\begin{array}{c}\text { Pounds Semi- } \\
\text { solid Butter- } \\
\text { milk }\end{array}$ & $\begin{array}{l}\text { Number of } \\
\text { Eggs Laid }\end{array}$ & $\begin{array}{c}\text { Average Weight } \\
\text { of Birds in } \\
\text { Pounds }\end{array}$ \\
\hline $\begin{array}{c}1924 \\
\text { November }\end{array}$ & 142 & 119 & 34 & 63 & 3.15 \\
\hline December & 141 & 113 & 34 & 10 & 3.32 \\
\hline $\begin{array}{c}1925 \\
\text { January }\end{array}$ & 167 & 109 & 34 & 92 & 3.76 \\
\hline February & 169 & 106 & 31 & 236 & 4.03 \\
\hline March & 169 & 111 & 34 & 663 & 4.02 \\
\hline April & 171 & 112 & 33 & 1005 & 4.04 \\
\hline May & 143 & 140 & 34 & 1032 & 3.78 \\
\hline June & 71 & 232 & 33 & 958 & 3.84 \\
\hline July & 67 & 233 & 34 & 973 & 3.82 \\
\hline August & 70 & 232 & 34 & 810 & 3.79 \\
\hline September 1st & & & & & 3.63 \\
\hline $\begin{array}{c}\text { Total } \\
(10 \text { months })\end{array}$ & 1310 & 1507 & 335 & 5842 & \\
\hline
\end{tabular}

Although the fowls of Lot 1 during January, February, March, and April were fed liberally, they consumed considerably less feed than the fowls in Lot 2, did not lay so well, and were slightly more than one-half pound lighter in weight at the end of that period. The maximum rate of egg production for Lot 2 was reached during April and May while with Lot 1 the maximum was reached about a month later.

HATCHING THE EGGS

All of the eggs laid by both lots of fowls from May 12 to 24, inclusive, were incubated in two 400 egg size Cyphers incubators. Table 5 gives the details of the hatch.

There was no appreciable difference in the fertility or hatchability of the eggs from the two lots of fowls. 
TABLE 5.-Fertility and Hatchability of the Eggs During the Second Year.

\begin{tabular}{|c|c|c|}
\hline Data Recorded for the Hatch & Lot 1 & Lot 2 \\
\hline $\begin{array}{l}\text { Number of eggs incubated } \ldots \ldots \\
\text { Per cent of eggs hatched ..... } \\
\text { Per cent of eggs fertile } \ldots . . \\
\text { Percent of fertile eggs hatched . }\end{array}$ & $\begin{array}{r}415 \\
83 \\
91 \\
90\end{array}$ & $\begin{array}{r}413 \\
82 \\
92 \\
89\end{array}$ \\
\hline
\end{tabular}

The two lots of chicks were toe-marked and then placed together in one flock. They were brooded in two Mammoth brooders and given free range during summer. The mortality from weakness or disease was reasonably low, the number of recorded deaths being 13 or 3.8 per cent for Lot 2 and 17 or 4.9 per cent for Lot 1 .

\section{WEIGHING THE CHICKS}

The chicks were weighed individually on September 19, 1925, when they were 96 days old. $U p$ to that time 5 had met accidental deaths, 25 had lost their distinguishing marks so that it was impossible to determine to which lot they belonged, and 48 were missing, probably having been caught by cats or crows. Table 6 gives the details of the weights of the 573 chicks remaining. This table shows that there was no difference in the weight of the chickens hatched from eggs laid by the two lots of fowls.

TABLE 6.-Weight of Chicks September 19, 1925.

\begin{tabular}{l|c|c}
\hline Data Recorded & Lot 1 & Lot 2 \\
\hline Number of males & 133 & 124 \\
\hline Number of females & 159 & 157 \\
\hline Mean weight of males & $2.21 \pm .02$ & $2.20 \pm .02$ \\
\hline Standard deviation in weight of males & $.28 \pm .01$ & $.26 \pm .01$ \\
\hline Mean weight of females & $1.74 \pm .01$ & $1.76 \pm .01$ \\
\hline Standard deviation in weight of females & $.21 \pm .01$ & $.22 \pm .01$
\end{tabular}

\section{Conclusion}

This experiment affords no evidence tending to show that a reasonably heavy egg production immediately prior to the hatching season has a detrimental influence on the fertility or hatchability of the eggs or on the vigor of the progeny. 

HECKMAN

BINDERY INC.

\section{JUNE 99}

N. MANCHESTER INDIANA 46962 
